\title{
FUTURE ENGINEERING EDUCATORS' PROFESSIONAL MOBILITY: CHALLENGES AND OPPORTUNITIES
}

\begin{abstract}
Malyshevskyi Oleh, Doctor of Pedagogical Sciences, Associate Professor at the Department of Vocational Education and Profile Technologies, Pavlo Tychyna Uman State Pedagogical University.
\end{abstract}

ORCID: 0000-0002-7653-7862

E-mail: omalysh67@gmail.com

\begin{abstract}
The paper substantiates the rationale for professional mobility formation in engineering educators. We emphasize the importance of professional mobility as a quality parameter of future engineering educators' training. The research outlines the main modernization tendencies in engineering and pedagogical education content contributing to future specialists' professional mobility. The study substantiates the principle of proactive training aimed at making engineering and pedagogical training oriented towards future professional activity of higher professional education seekers. We note that proactive training is crucial in determining educational program content as well as the choice of learning activity organization forms and educational technology for the intensification of engineering and pedagogical training and professional mobility formation.

Keywords: professional education, engineering and pedagogical education, professional mobility, engineering educator, proactive training, engineering and pedagogical training, professional education content, integrative processes.
\end{abstract}

\section{ПРОФЕСІЙНА МОБІЛЬНІСТЬ МАЙБУТНІХ ІНЖЕНЕРІВ-ПЕДАГОГІВ: ПРОБЛЕМИ ТА ПЕРСПЕКТИВИ}

Малишевський Олег, доктор педагогічних наук, доцент кафедри професійної освіти та технологій за профілями, Уманський державний педагогічний університет імені Павла Тичини.

ORCID: 0000-0002-7653-7862

E-mail: omalysh67@gmail.com

У статті обтрунтовано актуальність формування професійної мобільності інженерівпедагогів. Акцентовано на значенні професійної мобільності як показника якості підготовки майбутніх інженерів-педагогів.

Розглянуто специфіку інженерно-педагогічної освіти, метою якої є иілеспрямована підготовка гармонійно розвиненого спеціаліста, який поєднує у собі інженерні й педагогічні вміння. Наголошено на актуальності формування професійної мобільності у контексті інженернопедагогічної підготовки та необхідності модернізації ї̈ змісту. Зазначено, щзо інженернопедагогічна підготовка на засадах інтеграџіï освіти, науки й виробниџтва сприяє розвитку здатності до самоорганізачії, самовдосконалення $і$ конкурентоспроможності на ринку праці, до професійної адаптації; формуванню професійної мобільності.

Окреслено основні тендениії модернізащії змісту інженерно-педагогічної освіти, щуо забезпечують 


\begin{abstract}
професійну мобільність майбутніх фахівців. Обтрунтовано принцип випереджального навчання, метою якого є спрямування інженерно-педагогічної підготовки на майбутню професійну діяльність здобувачів вищої професійної освіти. Виокремлено напрями запровадження випереджального навчання. Зазначено, що випереджальне навчання є ключовим для визначення змісту освітніх програм, вибору форм організаиї освітньої діяльності й освітніх технологій для інтенсифікації інженерно-педагогічної підготовки та формування професійної мобільності.

3'ясовано чинники впливу, що обумовлюють професійну мобільність майбутнього фахівия. Доведено, щзо професійна мобільність у межах інженерно-педагогічної підготовки має чітко окреслений соціально-особистісний характер.

Ключові слова: професійна освіта, інженерно-педагогічна освіта, професійна мобільність, інженер-педагог, випереджальне навчання, інженерно-педагогічна підготовка, зміст професійної освіти, інтегративні процеси.
\end{abstract}

The beginning of the $21^{\text {st }}$ century characterized by strong global political, socioeconomic, cultural, scientific and technological information society development trends, together with the impact of digitization processes on all human activity fields, result in the need for radical changes in education. European integration processes, which have intensified in Ukraine in recent years, lead to a rapid exchange of human resources within the scope of economic, political, socio-cultural and educational relations. Such an exchange becomes possible, considering the development of a new human quality - constant personal and psychological (internal) as well as practical and activity (external) readiness for change in social and professional dimensions, a timely reaction to them, successful adaptation and professional growth in new conditions, i. e. professional mobility.

Professional mobility in the professional education system is considered as a future specialist's training quality parameter. The problem of the quality of labour is thus transformed into the problem of training professional education system graduates. It should be noted that it is not only about the formation of certain theoretical knowledge and professional skills but also about the development of professionally important competencies and universal personality traits, values and cultural behaviour norms in professional activities. It contributes to rapid adaptation in a business environment and the acquisition of techniques and technologies, making it possible to dynamically change a profession and be competitive in the labour market. Since the labour market, like any resource market, is affected by adaptive fluctuations, higher professional education should respond to fixed demand as well as take into account the effects of information and communication technology development and the ever-increasing need for highly qualified specialists. Since the role of higher professional education, which is at the forefront of social development as a major factor in the reproduction of human resources of the required quality, is changing significantly, there is currently an urgent problem of its operational reform.

The main theoretical principles and trends in the development and improvement of the content of professional education as a whole and engineering and pedagogical training, in particular, are substantiated in the works by A. Asherov, I. Bardus, S. Batyshev, H. Bakhtiiarov, V. Bezrukova, Y. Belikova, N. Briukhanova, R. Horbatyuk, R. Hurevych, A. Dzhantimirov, T. Kalinichenko, I. Kankovskyi, O. Kovalenko, V. Kruhlyk, L. Lukianova, N. Nychkalo, O. Novikov, M. Samoilova, V. Slastonin, L. Tarkhan, I. Tsidyla, O. Yurtaeva and others. At the same time, the problem of developing future engineering educators' professional mobility has not been adequately considered in scientific sources.

The article is devoted to the theoretical analysis of professional mobility development

ISSN 2706-6258 
in engineering educators, in the system of engineering and pedagogical education.

Professional education is now considered as a continuous process based on modern production needs for specialists' constant professional personality-oriented development and improvement as well as for expanding their capabilities in terms of qualitative changes in labour within one profession and in changing different professional spheres [1, p. 138].

The content of professional education should contribute to a level of the general and professional culture of society adequate for the world one; the formation of the worldview consistent with the modern level of knowledge and educational program; the integration of an individual into the national and world culture; the formation of a person and a citizen integrated into modern society and oriented towards its improvement; workforce capacity reproduction and development. At the same time, the development of higher professional education is possible only through its providers. The renewal of modern professional education is determined not so much by information and communication technology, and innovative pedagogical experience, as by teachers' fresh approaches as its implementers, their competence level, qualifications, professional and personal qualities. After all, according to $\mathrm{N}$. Nychkalo [6], a purposeful systematic improvement of a specialist's professional level is an important guarantee of obtaining employment in the labour market; it expands career opportunities stimulating the development of business activity and professional mobility.

Engineering and pedagogical training plays a leading role in the system of domestic professional education. Its methodological and theoretical foundations, structure, content and functions considerably differ from pedagogical or engineering ones. The Law of Ukraine "On Education" (Article 58) states that pedagogical education involves a person's training resulting in the acquisition of competencies in a specialty (subject specialty, specialization), pedagogy and psychology including through pedagogical internship necessary to provide the process of learning, education and personal development including for people with special educational needs, monitoring of educational work and the analysis of pedagogical experience, educational measurements, the application of educational technologies and teaching methods, effective ways of interaction among all participants in the educational process [8]. Engineering education is defined as a type of professional education that provides training for professionals in various fields of engineering [3].

Engineering and pedagogical education exist in two planes. Its specificity makes it possible to form a harmoniously developed specialist who has engineering and pedagogical skills, namely: design and solution of technical (industry) problems; organization of the educational process in professional (vocational) education institutions; development of new professional training techniques and methods and the provision of other kinds of pedagogical support, etc.

The main purpose of engineering and pedagogical education is not only personnel training for a country's economy, but also educating future professionals capable of performing pedagogical activities. Such candidates are characterized by a strong worldview and professional culture, ability to use innovative approaches to educational process modelling and research, as well as to apply proactive training tools and methods in the selfregulation and self-development mode.

Modern changes in the system of professional education require, in particular, effective solutions to important problems of updating the engineering and pedagogical training structure and content. This should definitely include the modernization and 
transformation of educational systems in a new socio-economic environment; the proactive training theory in the information and technological development of society; the scientific foundations of continuity, scientific and methodological support of all professional education levels; the development of professional education standards and more. In this regard, the engineering educator's activities consist of two types: professional (industry) and pedagogical.

O. Kovalenko emphasizes that engineering and pedagogical education is not a mechanical combination of two education types (engineering and pedagogical) but a qualitatively new type of knowledge characterized by the intersection of one subject area with the other as well as the close and rational integration of psychological and pedagogical, engineering and technical components in specialists' training. By the type of professional duties performed by its professionals, it belongs to the pedagogical one. However, the engineering and pedagogical activity subject is engineering and production technology training serving as an educational tool. In this case, technical and pedagogical knowledge form an integral system of knowledge and skills [5, p. 14].

The draft "Roadmap of Engineering and Pedagogical Education Development in Ukraine" states that the system of engineering and pedagogical education is a branch of pedagogical education aimed at training, retraining and advanced training of highly qualified educators for vocational (professional) education institutions, technical schools and specialized classes as well as training centers, and industrial training departments at industrial enterprises [5, p. 6].

Thus, at present, engineering and pedagogical education is a branch of pedagogical education aimed at the focused training and retraining of vocational training masters and special subject instructors providing educational services at all professional education levels as well as highly qualified engineers for various industries. In our opinion, the given engineering and pedagogical education interpretation implies the development of mobile specialists capable of their potential realization in at least two directions - at educational institutions and in the socio-economic sphere.

A characteristic feature of present-day engineering and pedagogical training is its focus on the social mandate of the future, as it remains the fact that the well-being of society depends on educational outcomes. Therefore, professional education content should include long-term requirements for the person as a subject of various social activities. Conceptually, it comes from the principle of proactive training.

The philosophical aspects of the advanced development of education are thoroughly covered by B. Hershunskyi. The scientist notes that the education sector, in principle, works for the future. At the same time, the special importance of educational and pedagogical prognosis is emphasized. It should underlie the prognostic substantiation of the tendency and continuous monitoring of changes in social environment factors that educational objects interact with. The projected results should be reflected in professional qualification profiles and models of educational institutions' graduates; in the content of curricula and educational programs and textbooks; in the implemented tools, methods and educational work organizational forms [2].

We support this scientist's idea because engineering and pedagogical education is focused on the future, in particular on professional activity conditions, which potential graduates will find themselves in. Thus, it should be centered around the formation of 
professional (industry) knowledge, creative and self-education skills, ability to orient themselves facing real professional dilemmas and to find effective ways and means to resolve them, i. e. the development of professional mobility.

Professional education development is impossible without adequate staffing. Recently, the problem of qualified personnel shortage that is capable of the development and successful operation of modern information systems, automated design and control systems, the effective use of digital technologies, etc. has become quite significant. The dynamism of the industry development entails rapid knowledge depreciation and requires continuous training of employees, supporting the information process in the workplace and at institutions.

The personnel problem should be solved first of all at the level of higher professional education through bachelor's and master's degree holders' training. To achieve this, it is necessary to choose correctly the conception of engineering educators' training. The development of their professional mobility is becoming an urgent problem in this context.

One of the main problems in future engineering educators' training at university is rather rapid depreciation of knowledge and skills. Great curriculum inertia does not allow a timely reaction to the emergence of new technology in the industry. At the same time, modern higher professional education is unable to adequately respond to the emergence of new computer technology, neither as a training aid nor as a future professional tool.

Thus, as can be inferred from the above, the problems of designing the educational process, starting from the professional education standards, come to the forefront of improving engineering and pedagogical training efficiency. The standards are also guided by the principle of proactive training, as it will be possible to assess their implementation results in the system of professional education only in 4-6 years. Their content should be based on systematic and well-coordinated prognostic studies.

The analysis and systematization of different approaches to the problem of proactive training conducted by P. Novikov and V. Zuev [7], allow us to identify three main aspects of this phenomenon interpretation: the content and nature of engineering and pedagogical education should meet the requirements of engineering and technologies at the design stage this approach is defined as predominantly predictive and technocratic aimed at reaching a maximum in the individual's professional activity; the number of participants in highly skilled mostly mental work should exceed the existing industry demand for personnel with such a qualification; the development of professional competencies should take place in order to increase the cost of labour and develop the potential of personnel capable of yielding high dividends of individual and social nature over a long period of time.

In light of the above, the engineering and pedagogical education process should ensure the formation of the following personal qualities: absolute mastery of professional competencies as well as ways to manage production processes and teams; commitment to professional duties including professional development; creative and conscientious attitude to professional activity; development of abilities to integrate knowledge and its rapid adaptation to new conditions; a prognostic approach to professional activity; a constant need for professional activity improvement. In this case, professional training becomes proactive.

The treatment of proactive training in such a context is crucial and determines the content of educational programs, educational activity organizational forms and the features of educational technologies that should ensure the scope and structure of professional knowledge, the nature of thinking and the individual's level of spiritual development as well 
as orientation towards long-term perspective. The organization of the educational process of engineering and pedagogical training in this way, in our opinion, will contribute to professional mobility development.

To determine the role of professional education in professional mobility formation, we consider the root causes of this pedagogical category emergence. According to S. Kaplina, there are two factors determining professional mobility: external and internal. The scholar explains external causes as global changes in the economy caused by the global trend of transition from an industrial to an information society. These reasons can be supplemented by external individual ones, such as a change of a profession, a job, a status in the organization, a place of residence, a state of health, etc. Internal causes, as the researcher notes, result from individual preferences, which can be determined by motivation of success, the individual's desire for the improvement of professional skills, self-development, etc. [4, p. 86-87].

Since the above external causes of professional mobility are beyond the influence of professional education, the development of the studied quality in the framework of engineering and pedagogical training has a clearly defined socio-personal nature.

Future specialists should be aware of their place and purpose in the surrounding world, and how their professional activity is related to social processes as well as their responsibility for the country's future and the need for the future engineering educator's diversity, flexibility and consistency of thinking. They should treat self-education as a source of ideas for making responsible decisions. The main emphasis in training should be placed on the development of graduates' mobility skills in their innovative professional activities.

Summarizing the above analysis, it should be noted that professional mobility itself is not essentially a professional education problem. It arises due to qualitative changes in social development processes and is governed by social relations. Future engineering educators' mobility is brought about by the growing dynamism of modern life, the constant updating of computers and information and communication technologies, the variability of social and especially professional activities as well as informatization of all public production branches and life spheres, etc. Although the reasons for mobility seem to be purely objective, it should be emphasized that professional education plays a very important role as a population professional mobility channel, because in the information society, changes in social and professional status (vertically or horizontally) are impossible without obtaining necessary qualifications.

However, engineering and pedagogical training if it is based on the principles of humanization and continuity, and when it is proactive in nature, can serve not only as a population mobility channel but also as a means of the purposeful development of society by forming professional mobility as future specialists' personal and professional quality in their training process. Thus, the development of professional mobility in future engineering educators at higher professional education institutions is one of the most important tasks, and the student's educational activities should combine the processes of independent search, creativity, the cultivation of norms and internal attitudes.

In recent years, the main trends in the development of engineering and pedagogical education content ensuring students' professional mobility include: increasing the number of specialties within professional education, which allows a timely response to the country's socio-economic demands; transition from knowledge to competence learning paradigm;

\section{ISSN 2706-6258}


professional education content differentiation due to the emergence of new educational programs; education content flexibility and variability due to the implementation of a modular approach, which contributes to the rapid renewal of education content in accordance with the development of modern science, technology and culture; the growing role of general scientific and general professional components of future professionals' training affecting the understanding of patterns and connections of facts and phenomena peculiar to future professional activity; the development of graduates' systemic professional thinking and professional competencies reflected in educational programs; engineering and pedagogical training content informatization and a more intensive use of distance learning to ensure students' self-education; the development of teaching staff contributing to the development and implementation of innovative educational programs and technologies; the improvement of forms, methods and means of educational process organization at higher professional education institutions; students' involvement in research activities and their start-ups modelling.

The analysis of domestic scientific literature gives grounds to conclude that increasing the quality of future professionals' engineering and pedagogical training is becoming quite an urgent problem and a prerequisite for professional education development as well as an incentive to update its content based on integrity, universality and variability. Nowadays, professional mobility serves as a qualitative indicator and an engineering and pedagogical training outcome. At the same time, professional engineering and pedagogical education is impossible without further study of its practical component, which ensures the transformation of integrated scientific achievements in various fields into professional competencies and promotes professional mobility formation.

For the purpose of finding optimal ways to form professional mobility in future engineering educators as their socio-personal characteristic, it is advisable to study this phenomenon from the perspective of a moral and volitional aspect. In our opinion, the professional mobility analysis, through the prism of volitional, moral and emotional qualities, will form a holistic vision of the future professional education specialist.

\section{СПИСОК ВИКОРИСТАНИХ ДЖЕРЕЛ}

1. Батечко Н. Г. Підготовка викладачів вищої школи в умовах магістратури: теоретико-методологічні засади: монографія / за ред. Я. В. Цехмістера. Київ: ТОВ «Видавниче підприємство «ЕДЕЛЬВЕЙС», 2014. 708 c.

2. Гершунский Б. С. Философия образования. Москва: Московский психолого-социальный институт. 1998.432 c.

3. Інженерна освіта. Енциклопедія сучасної Украӥни. URL: http://esu.com.ua/search_articles.php?id= 12289.

4. Каплина С. Е. Концептуальные и технологические основы формирования профессиональной мобильности будущих инженеров в процессе изучения гуманитарных дисциплин: дис. ... д-ра пед. наук: 13.00.08. Чебоксары, 2008. 569 с.

5. Концепція розвитку інженерно-педагогічної освіти в Україні: проект / кер. авт. кол. О. Е. Коваленко. Харків: [б. в.], 2004. 19 с.

6. Ничкало Н. Г. Неперервній професійній освіті- педагогічні кадри нової генерації. Проблеми інженерно-педагогічної освіти. 2005. № 10. С. 21-32.

7. Новиков П. Н., Зуев В. М. Опережающее профессиональное образование. Москва: РГАТиЗ, 2000. $266 \mathrm{c}$.

8. Про освіту: Закон України від 05.09.2017 p. № 2145-VIII. URL: http://zakon3.rada.gov.ua/ laws/show/2145-19. 


\section{REFERENCES}

1. Batechko, N. H. (2014). Pidhotovka vykladachiv vyshchoi shkoly v umovakh mahistratury: teoretykometodolohichni zasady [The training of higher educational establishments' teachers]. Ya. V. Tsekhmistera [Ed.]. Kyiv: TOV «Vydavnyche pidpryiemstvo «EDELVEIS» [in Ukrainian].

2. Gershunskiy, B. S. (1998). Filosofiya obrazovaniya [The philosophy of education]. Moskva: Moskovskiy psikhologo-cjtsialnyy institut [in Russian].

3. Inzhenerna osvita [Engineering education]. Entsyklopediia suchasnoi Ukrainy. URL: http://esu.com. ua/search_articles.php?id=12289 [in Ukrainian].

4. Kaplina, S. Ye. (2008). Kontseptualnye i tekhnologicheskie osnovy formirovaniya professionalnoy mobilnosti budushchikh inzhenerov $\mathrm{v}$ protsesse izucheniia gumanitarnykh distsiplin [Conceptual and technological basis for the formation of would-be engineers' professional mobility while studying social subjects]. Doctor's thesis. Cheboksary [in Russian].

5. Kovalenko, O. E. [et al.]. (2004). Kontseptsiia rozvytku inzhenerno-pedahohichnoi osvity v Ukraini: proekt [The concept of engineering and pedagogical education development in Ukraine: project]. Kharkiv: [n. p.] [in Ukrainian].

6. Nychkalo, N. H. (2005). Neperepvnii profesiinii osviti - pedahohichni kadri novoi heneratsii [Pedagogical personnel of a new generation for continuous professional education]. Problemi inzhenerno-pedahohichnoi osvity, 10, 21-32 [in Ukrainian].

7. Novikov, P. N. \& Zuev, V. M. (2000). Operezhayushchee professionalnoe obrazovanie [Advanced vocational education]. Moskva: RGATiZ [in Russian].

8. Pro osvitu [On Education]. № 2145-VIII (2017). URL: http://zakon3. rada.gov.ua/laws/show/2145-19 [in Ukrainian]. 